\title{
Gulliver; the Man-mountain, the Crumb, the Historian and the Polyglot
}

\author{
Ehsan Ekhtiari ${ }^{1} \&$ Fazel Asadi Amjad ${ }^{2}$ \\ ${ }^{1}$ Faculty of Letters and Foreign Languages, Islamic AzadUniversity, Karaj, Iran \\ ${ }^{2}$ Faculty of Foreign Languages, Department of English Literature, Tarbiat Moallem University, Tehran, Iran \\ Correspondence: Ehsan Ekhtiari, Faculty of Letters and Foreign Languages, Islamic AzadUniversity, Karaj, Iran. \\ E-mail: Ekhtiari1986@yahoo.com
}

$\begin{array}{ll}\text { Received: May 3, } 2012 & \text { Accepted: June 7, } 2012 \quad \text { Online Published: August 20, } 2012 \\ \text { doi:10.5539/ells.v2n3p1 } & \text { URL: http://dx.doi.org/10.5539/ells.v2n3p1 }\end{array}$

\begin{abstract}
Freedom, public's well-fare, science and religion are some of the topics which Jonathan Swift tried to deal with in most of his writings. In addition to that Swift was adroit in creating bizarre characters, Gulliver, Bickerstaff, Drapier to name just a few. In this article the researcher has tried to analyze the most famous among them-Gulliver. Gulliver is a character with different roles. In Gulliver's Travels, Gulliver plays four major roles. In each of them Swift conveys his criteria regarding the above mentioned topics to the reader. Language is Swift's mightiest weapon in his works. The role of language has been dealt with in this article. Another clash which exists in Gulliver's Travels is the clash of modernity and the classics and I think Swift always takes sides with the latter. This paper tries to concentrate on the roles which Gulliver has and to see if Gulliver is Swift's mouthpiece.
\end{abstract}

Keywords: politics, science, freedom, history, immortality, size and shape, language

\section{Introduction}

Who is Gulliver? What roles does he have? What is he meant to be? Among literary characters, one rarely finds a character like Gulliver. What makes Gulliver unique is not having extraordinary supernatural powers or being a chivalrous hero who saves the princess from the tower. His uniqueness lies in his multiplicity of roles, in his being a traveler who wins the confidence of the reader in compelling him to believe the existence of the places he depicts and what happens throughout the Travels. There is a disagreement among scholars on the fact of the congruence between Swift and Gulliver. Michael Seidel is cogent to say:

Swift, like Gulliver, is best known for a book of travel into several remote nations, and there is no denying that many of the political features of the nations Gulliver "discovers" are observable in political worlds in which Swift spent much of his life as a participant. The point of drawing these forced correspondences is not to suggest that Gulliver is modeled on Swift, but that Gulliver, like Swift's other first person narrators is a character created very much out of Swift's own world and as much able to represent the complexities of that world. (Richetti, 1996, p.208)

There can be other comments and quotations on the interchangeability of Swift and Gulliver, but the concern here is not to include them all, yet one may bring cases which show disparities between Gulliver and Swift which do exist. More instances and points about the two will be included and then conclusions will be made. Back to the questions, Gulliver is a character that stands nearer to the real world rather than to fictional sense; what makes Gulliver true to life is the fact that he is an ordinary human being who is prone to usual misery and suffering of life. To make the point clear, Gulliver is not like Prince Hamlet or Oedipus the King who is mighty people from the highest ranks of society whose hamartia brings about their downfall. Gulliver has four roles, which are granted to him in each of the four places where he goes to. In Lilliput, Gulliver is received on the island with hostility. He is pinned down to the ground, and is called the Man-mountain by the dwarf inhabitants of Lilliput. Lilliput is a state governed by a Queen. Gulliver is favored by the Queen until the fire breaks out at the palace and Gulliver extinguishes it by urinating on the palace which enrages the Queen extremely.

\section{Size and Shape}

Size and shape of the body are two factors which bear special meaning in the two first books of Gulliver's 
Travels. In Lilliput Gulliver is outsized, so he is Man-mountain. I believe the inhabitants of Lilliput are tiny in comparison to the bigness of Gulliver and Gulliver is giant because of some good characteristics he has shown of himself: love of his country, being at the service of public good, which respectively are shown in defending Lilliput against Belfascu by bringing some of the enemy's ships into their port and extinguishing the palace of the Queen. But this act which Gulliver calls an "eminent piece of service" was not well received by the Queen and she "in the presence of her chief confidents, could not forbear vowing revenge" (Swift, 1723, p.70). One of the Queen's confidents in Gulliver's Travels is a character named Bolgolam along with an admiral and some other characters who yearn ill-will for Gulliver and finally succeed in conspiring against Gulliver. Downie analyzes Bolgolam historically as "In many ways it is possible to view Bolgolam as a symbol for those Whigs who were enemies of Oxford, Bolingbroke, and Swift in the last years of Anne's reign and who threatened to wreak vengeance under the Hanoverians" (p.113).

Shape and size seem to have got a special position in Swift's philosophy. In part two of the voyage to Brobdingnag Swift proposes that "undoubtedly philosophers are in the right when they tell us, that nothing is great or little otherwise than by comparison" (Swift, 1726, p.94). Swift's friend, George Berkley (1685-1753) was one philosopher who emphasized the relativity of our judgment of size in his essay "Toward a New Theory of Vision" (1709). In Book Two, unlike Book One Gulliver is a dwarf in Brobdingnag and is received with hostility and disgust, as if he were a weasel. In Book Four of the Travels, Gulliver is paralleled to a Yahoo and the Houyhnhnms are horses. It is suggested by critics among them Majorie Nicolson that "Gulliver becomes a metaphorical microscopist in Lilliput, where he is elevated observer of small creatures and objects and even more so in Brobdingnag where his scientific curiosity is complemented by a perspective that makes everybody object to him in magnified detail" (Bloom, 2009, p.193). Brobdingnags are giant because they are virtuous practical and in Alan Bloom's words because "They are, particularly, temperate. Political life is not a plaything of their lust". (Greenberg, 1970, p.302) Yet in the eighteenth century, body and its shape were dealt with by many writers. Carol Houlian Flynn (1990) writes, "The problem of the body becomes one of the central concerns of the eighteenth century, dominating the works not Defoe and Swift, but to name a few-Smollett and Sterne, Fielding and Richardson Boswell and Johnson, Pope and Hogarth, Burney and Thrale" (p.6). Although this article is not to analyze Gulliver's Travels under a specific literary approach but Felicity A. Naussbaum has a feministic perspective on the meaning or the significance of the body in different books of the Travels.

In the first two parts, the voyages to Lilliput and Brobdingnag the female body becomes a substitute for the notion and the concept of women a metaphor for mother country. In part three the floating island, Laputa, is sexual rather than maternal in its associating with the Spanish la puta, the whore. Finally in part four the notion Gulliver visits is the epitome of masculine reason while the servant class, the yahoos, are feminized in their slatternly otherness. (Fox, 2003, pp.322-323)

For Swift the size of the inhabitants of the two first parts is at the service of depicting ideals or notions which make men especially the modern man, tiny or big. Morality, temperance, love of one's country, hatred of tyranny, ethical utility of learning, brevity of speech, the supremacy of reason over passion, are ancient ideals which were depicted in Plato's Republic, Sparta or other works. The king of Brobdingnag is among the admirable characters in Gulliver's Travels, while the Emperor of Lilliput is a despot who wants to make "the whole Empire of Belfascu into a province" (Eugene H. Hammond, 1982, p.447). The King of Brobdingnag hates the idea of gunpowder proposed by Gulliver.

Gulliver is a crumb in Brobdingnag because in the first place Swift is comparing Gulliver as a modern man, as a European with the ideals of the ancients bringing the former's tininess to the front, and in the second place as mentioned before, like in Lilliput, Gulliver is an observer in Brobdingnag whose scientific curiosity is complemented by a perspective that makes every object to him in a magnified detail. Microscope was an invention in 1600s, it was mainly used by scientists but as Deborah Needleman Armintor quotes Majorie Nicolson "it (the microscope) had become a popular female commodity" (in Bloom, 2009, p.195). Gulliver is a crumb, a toy in the hands of Glumdalclitch and an object for the public show later in the chapter. Thirdly Gulliver is changed to a mercantile object, foreshadowing the corrupted nature of a human-being. Alan Bloom gives an explanation why there are differences of physical size between Lilliputians and Brobdingnags, "Swift's advice in Lilliput and Brobdingnag is to take moral and intellectual differences and project them in physical dimensions" (Greenberg, 1970, p.299). Passing the first two places, Gulliver enters the third place, Laputa, taking his third role.

\section{Science}

Unlike the first two places, in the third place Gulliver is a non-involved observer, he resided in Lilliput and 
Brobdingnag but here he is a guest or a tourist. Book three of the Travels was written after the other three books, while books one, two and four seem more down to earth and real; book three enters the realm of fantasy. The reader is introduced with a flying island which is a means of oppressing the citizens living below. Along with the flying island, having in mind the land of Luggnagg and Struldbruggs makes the third book nearer to science fiction novels and fairy tales. Yet, Swift's artistic presentation of the third book by no means is fortuitous. Some notions which are modern concerns of life have been ridiculed or criticized. Science, man's wish to live eternally and history are the main targets of Swift.

In Book Three, Swift attacks Newton and the Royal Society. It is noteworthy to include that Swift was not against the kind of science which is practical and useful to the "public good". He is furious at those experiences or sciences which were exercised for showing off one's glorification. Bonamy Dobrée (1959) confirms that "Swift, as far as we know, did not despise science what he objected to was the self glorification of the petty virtuoso dissecting flies, and the absurd pretentions of the second-rate scientists to 'explain' the inexplicable" (p.456). Swift was not an ignoramus person regarding science; he studied Descartes, Gassendi, and Newton, but as Herbert Davis explains:

Like most of his contemporaries he approved of the activities of the scientists in so far as their work could be of practical use in agriculture and manufacture and navigation and medicine. But he feared the quackery and conceit of these investigations and logically was driven to make his attack on all kinds of technical jargon, as the very symbol of that kind of speculation which was in danger of separating its activities from all connexion with the common needs of man. (Greenberg, 1970, pp.426-427)

Gulliver on his arrival to the flying island Laputa observes and accounts how the inhabitants leave or enter Laputa using a rope. We are informed that the King can raise the island to deprive the people from the falling of "Rains and Dews". "It is in the power of the Monarch to raise the island above the region of clouds and vapours, he can prevent the falling of Dews and Rains whenever he pleases" (Swift, 1726, p.161).

\section{Politics}

In addition to science, politics is the next target which Swift does not hesitate to blatantly attack. Tyranny, oppression, slavery are the concepts which enrage any liberal spirit as Swift's. Politics is a dominant topic in Gulliver's Travels, and especially in the first book. In chapter one, we cannot take Gulliver for Swift, since historically speaking, Swift was favored and supported by Queen Anne. Dr. Samuel Johnson believes that in the reign of Queen Anne, Swift "dictated for a time the political opinions of the English nation" (Goldgar \& Gadd, 2003, p.43). Thus we can take Gulliver for one of Swift's closest friends Bolingbroke. J. A. Downie (1977) argues that "Gulliver is a complex figure representing sometimes Oxford, sometimes Bolingbroke, and no doubt, occasionally Swift himself. And this strange creature Gulliver / Oxford / Bolingbroke / Swift, was, in certain instances meant to symbolize the fate of all three real men on 'political characterization in Gulliver's Travels" (p.112). Historically speaking Swift played an important role in the Wood's Half-pence Act and that accounts for why in many of his works Swift craves to propagate love of one's country, patriotism and hatred toward slavery. Carole Fabricant notices "the image of the Irish patriot as brogue wearer and potato eater is perhaps Swift's boldest contribution to the struggle against Wood's half-pence underscoring the extent of his identification with a larger, more inclusive Ireland than one embraced by others in his class" (Fox, 2003, p.58). Another instance is Swift's Proposal for the Universal Use of Irish Manufacture (1720), by which Swift urged a nationwide boycott of English manufacture, Patrick Kelly mentions that "the three decades following the publication" of the mentioned work "there was a period of astonishing fecundity for economic literature in Ireland" (Fox, 2003, p.141).

Biographically speaking, Swift wrote many economical writings; though difficult to enumerate, Kelly has counted some of them, A Short View of the State of Ireland in "the intelligence No.15 on the title page of $A$ Scheme for Giving Badges to Beggars and the legend of M. B. Drapier" (Fox, 2003, p.141). Kelly adds that "central to understanding what motivated Swift's writing on economic matters is his deep ambivalence towards Ireland and her problems" (ibid 141). And finally she concludes that Swift's ultimate objective in his economic writings is the practical manifestation of love of country through doing goods to the public" (ibid 142).

Swift was an anti-colonialist writer; he would oppose exploiting other nations in the name of "civilizing" them. Swift was a true proposer of freedom. "Swift had written to his friend Charles Ford in London on 4 April, 1720, when both Delatory Act and South Sea Act had been passed by the British Parliament and were awaiting the King's signature, that he was concerned whether the Irish should be "slaves"' (Bloom, 2009, p.15). Bonamy Dobrée (1959) explains that for Swift "the appeal is not the pocket but altogether to pride, not to finance, but to the sense of freedom" (p.437). 
Were not the people of Ireland born as free as those of England? How have they fortified their Freedom? Is not their Parliament as fair as a Representative of the people, as that of England? And hath not their privy council as great or a greater share in the Administration of Public Affairs? Are they notsubjects of the same King? Does not the same Sun shine over them? And have they not the same God for their protector? Am I a Freeman in England and do I become a Slave in six hours by crossing the channel? (p.437)

Swift first criticized England's treatment of Ireland and then was against "the self-glorification of the petty virtuoso dissecting and the absurd pretentions of the second-rate scientist to "explain' the inexplicable" (Dobrée, p.456). "This may perhaps pass with the Reader rather from a European or English story, than for a Country so remote" (Swift, 1726, p.160). In this part Gulliver is Swift's mouthpiece.

\section{History and Immortality}

As indicated earlier, Gulliver is like a tourist; he recounts his observations in part three. There is an Academy of Projectors where Gulliver is invited to pay a visit. This Academy is a very big place, a forum for projectors of scientists and mostly resembles the Royal Society of London. The Academy is depicted as a modern place opposed to the ancient. The other place where Gulliver goes is Glubdubdrib or "the land of sorcerers or magicians". This part along with Laputa-the flying island makes the Travels a sort of science-fictional novel. In Glubdubdrib Gulliver when understands about the magic of summoning the dead asks for an admittance to the governor who has the ability to do the magic. "I would chuse to name, and in whatever Numbers among the Dead from the beginning of the world to the present time... and one thing I might depend upon, that they would certainly tell me Truth; for Lying was a Talent of no Use in the lower World" (Swift,1726, p.184). Lying is a vice and also "a talent of no use" and it is certain for Gulliver and rather Swift that the answers received from the dead will be authentic and reliable.

One of the tasks which Swift puts on Gulliver's shoulders to take is to be a historian. Swift praises a Roman historian and suggests historians should have justice in their retelling accounts. Later in chapter ten, in the land of Struldbrggs, Gulliver enumerates three wishes he would like to do if he had been a Struldbrugg and the last one is to "record every Action and Event of consequence that happened in the publick" (Swift, 1726, p.195). Gulliver desires to visit many people ranging from Brutus, Junius, Socrates, Epaminondas, Cato the Younger, Alexander, Hannibal up to Sir Thomas More. On the encounter of Alexander; Gulliver says, "He assured me upon his Honour that he was not poisoned, but dyed of a Fever by excessive Drinking" (Swift, 1726, p.184). And Gulliver continues "I chiefly fed mine Eyes with beholding the Destroyers of Tyrants and usurpers, and the Restorers of Liberty to oppressed and injured Nations" (Swift, 1726, p.185).

Swift as a defender of liberty and freedom will later admire the ancients, men of wit and learning and those who restored liberty to "oppressed and injured Nations" and will compare modern and ancient history and will comment on them. Gulliver wants to meet some people of learning and wit including, Aristotle, Homer, Descartes, Gassendi and others. Swift puts his words in Gulliver's mouth as; "I was chiefly disgusted with modern History" (Swift, 1726, p.187). Swift will later tell the reader the reason why he hates the modern history. I had often read of some great Services done to Princes and States, and desired to see the Persons by whom those Services were performed. Upon Enquiry I was told, that their Names were to be found on no Record, except a few of them whom History hath represented as the vilest Rogues and Traitors. (Swift, 1726, p.189)

Gulliver at the end makes a comparison between the people of the past and the modern era and regrets for their corruption, while Swift adroitly shows the diminution of the modern men by diminishing the body size, "How the pox under all its consequences and Denominations had altered every Lineament of an English countenance, shortened the Size of Bodies, unbraced the Nerves, relaxed the sinews and muscles, introduced a sallow complexion, and rendered the Flesh loose and rancid" at the end of chapter eight of book three, Gulliver yearns to have "some English Yeomen of the old Stamp" summoned and makes the final comparison and conclusion between the modern people and the ancient.

Once so famous for the simplicity of their matters, Dyet and Dress for Justice in their Dealings, for their spirit of Liberty, for their valor and love of their country. Neither could I be wholly unmoved after comparing the Living with the Dead, when I considered how all these Pure native virtues were prostituted for a piece of Money by their Grand-Children; who in selling their votes, and managing at Elections have acquired every vice and corruption that can possibly be learned in a court. (Swift, 1726, p.190)

To understand what the main root of this corruption, according to Swift is, we should remember Gulliver's comment earlier in this chapter. "I was surprised to find corruption grown so high and so quick in that Empire, by the Force of Luxury so lately introduced" (Swift, 1726, p.189). Ian Higgins (1983) suggests in his article that "For Swift it was luxury prevented from developing in primitive Sparta and absent from Houyhnhnmland that 
accounted for the physical and moral degenerations of his contemporaries" (p.528).

The next place which Gulliver visits is the land of Luggnuggians where there are Struldbruggs or immortals. It has been Man's probably the oldest wish to be immortal, and depicting immortal beings in book three makes this book more fantastical. Back to Gulliver's role as a historian, Gulliver likes to see "the various Revolutions of States and Empires", and to recount the State of ancient cities, "ancient cities in Ruins, and obscure villages become the Seats of Kings" (Swift, 1726, p.196). "The Discovery of many countries [is] yet unknown. Barbarity overrunning the politest Nations, and the most barbarous becoming civilized" (Swift, 1726, p.196).

The two latter lines, historically speaking can refer to great Empires of Rome, Persia and ancient Greece which by the passage of time have lost their dominance and glory and have become barbarous countries and on the other hand new cities or newly discovered countries have come to the front and have tried to colonize other countries in the name of "civilization". Nigel Dennis says, "Swift's islands are never menaced by barbarism; on the contrary, the only atrocities he finds are those of the civilized cultured persons who have degenerated grossly from the happier natural state of man and have espoused reason only in order that "the corruption of the faculty might be worse than brutality itself'(Greenberg, p.366).

\section{Language}

The last notion which I want to deal with is language. Language is a strong weapon in Swift's hands to satirize and attack the targets he has in mind. The text of A Tale of a Tub, Swift's master-piece he wrote in his youth is different from the text and language of his second masterpiece- Gulliver's Travels, written later in his life. The language Swift uses to write A Tale of a Tub is not easily understood by a student of English language, while the language of the Travels, is easily understood and is by far more clear. Yet Swift created different languages in each voyage and place Gulliver is thrown into. Although in certain cases some guesses or implications have been made by scholars but the meaning of the words or phrases stay vague on the whole. "Hekina Degul", "Borach Mivola", "Peplom Selan" are the words said by people of Lilliput the first place he visits. Gulliver's Travels abounds in having such words or phrases, few of them have been deciphered by some scholars, "Tribnia" or "Langden" have been cogently noticed to be Britain and England. Gulliver's ability to learn or speak different languages by the time he is staying in the second chapter gets quite obvious. In the first voyage Gulliver says: "I spoke to them in as many Languages as I had the least Smattering of, which were High and Low Dutch, Latin, French, Spanish, Italian, and Lingua Franca" (Swift, 1726, p.49). Gulliver looks like a polyglot, actually he is a polyglot. At the same time Gulliver is a sort of Linguist. Biographically speaking Swift knew to write and speak French well, also Swift was well read in Greek and Roman writers. In this part Gulliver is identical with Swift too. In chapter one of the first voyage, Gulliver is captured by Lilliputians and can communicate by the help of an interpreter and later he learned the language and could speak it. In the second Book, the voyage to Brobdingnag, Gulliver is given to a nine-year old-Glulmdalclitch or "little nurse", and Gulliver says, "she was likewise my school-mistress to teach me the language: when I pointed to anything, she told me the Name of it in her own Tongue, so that in a few Days I was able to call for whatever I had a mind to" (Swift, 1726, p.101).

In Book three when Gulliver sets off his voyage to Laputa, he is attacked and his ship is captured by some pirates; one of the chiefs is a Japanese pirate and the other one is a Dutchman, Gulliver says, "I spoke Dutch tolerably well" (Swift,1726, p.150). On his arrival to Laputa, Gulliver says, "At length one of them called out in a clear, polite, Smooth Dialect, not unlike in sound to the Italians, and therefore I returned an Answer in that language, hoping at least that the Cadence might be more agreeable to his Ears" (Swift,1726, p.153). In this book, in addition to Gulliver's ability to speak and learn different languages, it seems he is like a linguistic; a person who can detect defects or shortcomings both in producing sounds and discourse as well as grammatical malfunctions. "It seems the minds of these people are so taken up with intense speculation, that they neither can speak, nor attend to the Discourses of others, without being roused by some external Taction upon the organs of Speech and Hearing; for which Reason, those Persons who are able to afford it, always keep a Flapper" (Swift, 1726, p.154). Another instance is when Gulliver wants to give the meaning of the word Laputa, he says, "The word, which I interpret the Flying or Floating Island, is in the Original Laputa, whereof I could never learn the true Etymology" (Swift, 1726, p.156).

In about a month's Time I had made a tolerable Proficiency in their Language", these are the finishing lines of Gulliver in chapter two of the third book which show Gulliver's ability to learn languages. In chapter five of the third voyage where Gulliver is permitted to see the Academy of Lagado, Gulliver goes to the school of Languages and recounts what is going on. "Their first project was to shorten Discourse by cutting Polysyllables into one and leaving out Verbs and particles; because in Reality all things imaginable are but Nouns (Swift, 1726, pp.175-176). 
"The other was a Scheme for entirely abolishing all Words whatsoever. An expedient was therefore offered, that since Words are only Names for Things, it would be more convenient for all Men to carry about them, such Things as were necessary to express the particular Business they are to discourse on" (Swift, 1726, p.176). Then Gulliver goes on to ridicule this idea, proposing that everyone would carry a bag of loads with himself and if they want to talk for a long time they can "lay down their Loads" and talk for "an Hour together", and further Gulliver sarcastically adds another advantage; "Another great advantage proposed by this invention, was, that it would serve as an universal Language to be understood in all civilized Nations, whose Goods and utensils are generally of the same kind" (Swift, 1726, p.176).

Swift's bitter censure on these innovations is rooted in his strict use of language and grammar. A. L. Rowse (1975) says, "Swift was a conservative, and a stickler for strict grammatical usage" (p.177). Swift's rage of what was happening to English language at his age made him outcry it by delineating ridiculous ideas as presented by the professors of the School of Languages. In chapter seven of the third book where Gulliver is in Glubbdubdrib, on his encounter with Alexander, Gulliver says; "with great Difficulty I understood his Greek". In the land of Struldbruggs Gulliver says; "I understand the Balnibarbian language, which I spoke very well". And in the tenth chapter, Gulliver acts like a linguist and says;

The language of this country being always upon the Flux, the Struldbruggs of one Age do not understand those of another; neither are they able after two Hundred Years to hold any conversation (Farther than by a few general Words) with their Neighbours the Mortals; and thus they lye under the Disadvantage of living like Foreigners in their own country. (Swift, 1726, p.199)

And the third book finishes once again with the fact that he could speak Dutch well. "I had long lived in Holland, pursuing my studies at Leyden, and I spoke Dutch well" (Swift, 1726, p.202). In the first chapter of the last book, on the encounter of the Houyhnhnms, Gulliver describes their language as, "I plainly observed, that their language expressed the passions very well, and the Words might be little Pains be resolved into an Alphabet more easily than the Chinese". In chapter two of the fourth book while Gulliver was at party says; "the master taught me the Names for oats, milk, fire, water, and some others; which I could readily pronounce after him; having from my youth a great Facility in learning Languages". Swift's presence here behind Gulliver is extremely palpable, there is no argument to say, Swift had a good ability in learning languages, he knew French and English, and he read great works of Rome and Athens. In chapter three of book four, Gulliver tries to learn the language of the Houyhnhnms, "In speaking, they pronounce through the Nose and Throat, and their Language approaches nearest to the High Dutch or German, of any I know in Europe; but is much more graceful and Significant" (Swift,1726, p.215). Our linguist tells us the etymology and meaning of Houyhnhnm, "The word "Houyhnhnm", in their tongue, signifies a "Horse"; and its Etymology, the "Perfection of Nature".

In learning the language of Houyhnhnms Gulliver sets his quickest record in learning a language "in five months from my arrival, I understood whatever was spoke[n], and could express myself tolerably well" (Swift, 1726, p.217). In one chapter before the last on the way home from Houyhnhnmland, Gulliver is taken on board of a ship and the crew and the captain of the ship are Portuguese, "one of the seamen in Portugueze bid me rise, and asked who I was. I understood that Language very well” (Swift, 1726, p.257). First of all what makes Gulliver a polyglot or one who has any eye for languages lies in his extensive reading.

My Hours of Leisure I spent in reading the best Authors, ancient and modern, being always provided with a good Number of Books; and when I was ashore, in observing the Manners and Dispositions of the people, as well as learning their Language, wherein I had a great Facility by the Strength of my Memory. (Swift, 1726, p.40)

In the second place, being a traveler of an ordinary skill and knowledge one starts learning a language by staying in a place and will develop it in a proper period of time up to a perfect command of that language. Gulliver's emphasis throughout the Travels and particularly in the last chapter of the last book is that he adhered to truth and what he wrote was not a pack of lies. "I imposed on myself as a Maxim, never to be swerved from, that I would strictly adhere to Truth" (Swift, 1726, p.262). What Gulliver is doing is to recount his travels, we should bear in mind that the aim of the travels is to inform not to amuse; and to vex the world as Swift intended, the prerequisite is to gain the confidence of the reader, perhaps if Gulliver could not speak the language of the places he visited, we would doubt the authenticity of the retellings, because we could consider some room for the probable misinterpretations or misunderstanding between Gulliver and his interpreters while now we know Gulliver has himself understood the conversations and thus the retellings is what Gulliver felt and experienced.

\section{Who Is Gulliver?}

Back to the question posed at the beginning of this article. Who is Gulliver? What is he meant to be? Gulliver is a multi-faceted character, hence finding or associating a real person who he may represent is by no means an 
easy task to do. Are Swift and Gulliver the same? Is Gulliver a politician of Swift's time, as J. A. Downie says “... representing sometimes Oxford, sometimes Bolingbroke, and, no doubt occasionally Swift himself”? (p.111) and Downie continues that "This strange creature, Gulliver, Oxford, Bolingbroke, Swift, was, in certain instances, meant to symbolize the fate of all three real men on the accession of George I" (p.112). As discussed in this article earlier, Gulliver is meant to have different roles, on the whole we cannot say that Gulliver and Swift are one, but there is no argument that in certain parts Gulliver is Swift's mouthpiece.

For instance, in book one, Gulliver was accused of being a traitor after doing a great deal in defending Lilliput against Belfascu, Carol Fabricant says "in the years immediately following his return to Ireland in 1714, Swift fell afoul of the Whig authorities, who falsely suspected him of Jacobitism... hence treated Swift as a potential traitor" (Fox, p.54). By this comparison, we can conclude that Swift and Gulliver are the same in chapter one of the first voyage. Swift was an important figure both in the world of politics and literature, in his time. Dr. Samuel Johnson believes that "in the reign of Queen Anne Swift dictated for a time the political opinions of the English nation" (Goldgar \& Gadd, p.43). Swift had a prominent role in his age, Gulliver was a giant in the society of Lilliput he was an outsize for the society.

In book two, however, Gulliver is tiny in the hands of the giant Brobdingnags. In book two, Brobdingnags are representations of virtue, apoliticism, pragmaticality, the notions which the modern society had lost them and had generated their opposites, vice, politics and fancy. Gulliver is a normal modern man and that is what makes him tiny; not only Swift and Gulliver are not identical with each other but two different poles. Downie (1977) says, "Swift's own views are voiced through the vehicle of the King (of Brobdingnag) in competition to no one, and evading the possible confusion of using Gulliver as his medium" (p.120). The king of Brobdingnag gives his comment on human beings:

How contemptible a Thing was human Grandeur, which could be mimicked by such diminutive insects as I: And Yet, said he. I dare engage; those Creatures have their Tiltles and distinctions of Honour; they contrive little Nests and Burrows, they love, they fight, they dispute, they cheat, they betray. And thus he continued on, while my colour came and went several Times, with Indignation to hear our noble country, the mistress of Arts and Arms, the Scourge of Truth, the Pride and Envy of the World, so contemptuously treated. (Swift, 1726, p.112)

Downie has rightly said that "Swift's own views are voiced through the vehicle of the King", the houses are described as "nests" and "burrows", Swift will later in chapter two of the third book comment on the modern houses built and the problems and illogical construction. "Their Houses are very ill built, the walls bevil, without one right Angle in any Apartment, and this defect ariseth from the contempt they bear for practical Geometry, which they despise as vulgar and Mechanick" (Swift, 1726, p.157). Swift was for simplicity; he considered luxury a starting point for corruption, luxury in building houses or in everyday life was not appealing to Swift. Bonamy Dobrée tells us that:

It was this aristocracy which built throughout the century the great country houses, beginning with Vanbrugh's Castle Howard, such houses as Stowe, Hagley, Badminton, Wentworth Woodhouse Holkham, Lydiard Tregoz and Harewood, together with numberless smaller gems with these went the landscape gardens, the parks, the hills, all contrived to make houses like jewels in a setting, a vogue fostered by the poets from Pope to Shenstone. (p.390)

The model and ideal structure of houses, which Swift suggests is the ancient ones. "We came at length to a house, which was indeed a noble structure, built according to the best Rules of ancient Architecture" (Swift, 1726, p.168)

In Books Three and Four, unlike the first two books, the size of body is not an important vehicle, nor is satiric, in chapter III; Gulliver an observer who visits Academic places where are considered the sources of modern science. Gulliver is like a reporter, he reports whatever he sees in the Academy of Legado and recounts it. Modern science is not adored by Swift because it is not first of all pragmatic but some abstractions to Swift and secondly not "for public good", so they are absurd. Deism proposed and defended by figures such as Descartes and natural religion posed by Locke together were dominant philosophical credos of Augustan Age and Deists proposed that people could use reason, and reason was enough and according to A. Lewis Soens, Jr. and Patrick Salerno (2001) "with these faculties people could then arrive at religious truth; they did not need biblical revelation" (p.85). Deism can lead to immorality that's why Swift depicts the scientists as absurd at the same time very proud. Pride is the starting point of corruption of human beings. According to Dobrée, Swift did not hate science, "Swift as far as we know, did not despise science; what he objected to was the self-glorification of the petty virtuoso dissecting flies and the absurd pretentions of the second-rate scientist to "explain the inexplicable" (Greenberg, p.388). 
In Book Four, Gulliver is in Houyhnhnland, Houyhnhnms and Yahoos are the inhabitants of that land. Houyhnhnms are horses and Yahoos are beasts which resemble most a human-being. Gulliver our average modern man is struggling in finding out to which group he belongs, he tries to attribute his characteristics to a Houyhnhnm while at the end he succumbs in accepting that he belongs to the Yahoo race. Swift is using his old weapon-satire, as A. E. Dayson says, “... the satirist holds up a mirror for his readers to see a distorted image and the reader is to be shocked into a realization that the image is his own" (Greenberg, p.351).

\section{Conclusion}

Swift has stated that his aim is to "vex" the world in his works especially in Gulliver's Travels. When one reads the last book and is confronted with the disgusting image of man, his pride and his irrational way of reasoning, being under the lashes of Swift, one may reach an epiphany. The epiphany is that man's pride can and will bring about his final downfall. By quoting Sir Walter Scott, I would want to draw conclusion on what Gulliver is meant to be or who he is....but Swift seems, like the Persian dervish, to have possessed the faculty of transfusing his own soul into the body of anyone whom he selected, of seeing with his eyes, employing every organ of his sense, and even becoming master of his judgment. Lemuel Gulliver the traveler, Isaac Bickerstaff the astrologer, the French man who writes the new Journey to Paris, Mrs. Harris, Mary the cook-maid, the projector who proposes a plan for relieving the poor by eating their children, and the vehement Whig politician who remonstrates against the enormities of the Dublin Signs, are all the persons, as distinct from each other as they are in appearance from the Dean of St. Patrick's. Each maintains his own character, moves in his own sphere, and is stuck with those circumstances which his situation in life or habits of thinking have rendered most interesting to him as an individual. (Williams, p.300)

Scott is very right when he says Swift had indeed the ability to transfuse "his own soul into the body of anyone whom he selected", our character under question, Gulliver, is not a copy of Swift or totally the mouthpiece of Swift, yet the presence of Swift behind Gulliver is sometimes unquestionably undeniable. As discussed earlier in books one and two in certain parts of Gulliver's Travels, Gulliver and Swift are interchangeable. In books three and four rather Gulliver is not easily distinguishable as Swift's sub, however there are instances which we can feel Swift's presence. For instance in book three while Gulliver is commenting on the Architecture of the modern houses and the ancient ones we know he is voicing Swift's ideas; the clash between modernity and the ancient. In book four Swift's habit of spending time with his horses is paralleled by Gulliver's resort and speaking with the horses.

Gulliver is meant to be an average modern man who is proud and at the same time he was in the first place an honest traveler, a diplomat, a defender of his country, a patriot, a well-read man in letters both modern and ancient, and a polyglot. These qualities were the roles Swift had in his life, therefore Swift attributes his abilities to Gulliver, that's what makes us see Gulliver partly as a persona of Swift and other part as a creation of fiction, but it is safe to say the proportion of the part of Gulliver which represents Swift is to my point of view more dominant and within reach to recognize.

\section{References}

Bloom, Harold. (Ed.). (2009). Jonathan Swift's Gulliver's Travels. New York: Infobase.

Dobrée, Bonamy. (1959). The Early Eighteenth Century 1700-1740, Swift, Defoe and Pope. Oxford: Clarendon Press.

Downie, J. A. (1977). Political Characterization in 'Gulliver's Travels'. In The Year Book of English Studies (Vol. 7, pp.108-120). Retrieved November 6, 2011 from http://www.jstor.org/stable/3507260

Flynn, Houlian Carol. (1990). The Body in Swift and Defoe. New York: Cambridge University Press.

Fox, Christopher (Ed.). (2003). The Cambridge Companion to Jonathan Swift. New York: Cambridge University Press.

Goldgar, B. A., \& Gadd, Ian (Eds.). (2008). English Political Writings. New York: Cambridge University Press.

Greenberg, A. R. (Ed.). (1970). Gulliver's Travels. New York: W. W. Norton \& Companion, Inc.

Hammond, R. Eugene. (1982). Nature-reason-justice in Utopia and Gulliver's Travels. Studies in English Literature, 22(3), 445-468. Retrieved from http://www.jstor.org/stable/450241

Higgins, Ian (1983). Swift and Sparta: The Nostalgia of 'Gulliver's Travels'. The Modern Language Review. 78(3), 513-531. Retrieved November 6, 2011 from http://www.jstor.org/stable/3730227

Richetti, J. (1996). The Cambridge Companion to the Eighteenth Century Novel. New York: Cambridge 
University Press. http://dx.doi.org/10.1017/CCOL0521419085

Rowse, A. L. (1975). Jonathan Swift. New York: Charles Scribner's Sons.

Salerno, Patrick, \& Soens, Lewis A. Jr. (2001). Cliff Notes Gulliver's Travels. New York: Wiley Publishing, Inc.

Swift, J. (1726). Gulliver's Travels. Rawson, Claude (Ed.). (2005). New York: Oxford University Press.

Williams, K. (1970). Swift: The Critical Heritage. London: Routledge \& Kegan Paul limited. http://dx.doi.org/10.4324/9780203196953 